\title{
PENGEMBANGAN BAHAN AJAR TEMA PERISTIWA DALAM KEHIDUPAN (PERUBAHAN WUJUD BENDA) BERBASIS SAINTIFIK DI SD NEGERI 008 SANGATTA UTARA
}

\author{
Kasmiah Gaffar \\ Universitas Mulawarman \\ kasmiahgaffar@gmail.com
}

\begin{abstract}
ABSTRAK
Tujuan penelitian ini adalah untuk mengembangkan bahan ajar, kepraktisan, keefektifan dan mengetahui perbedaan sebelum dan sesudah menggunakan buku ajar Tema Peristiwa Dalam Kehidupan Berbasis Saintifik Di SD Negeri 008 Sangatta Utara. Penelitian ini merupakan penelitian pengembangan atau Research \& Development (R\&D). Research and Development adalah metode penelitian yang digunakan untuk menghasilkan produk tertentu dan menguji kevalidan, kepraktisan dan keefektifan produk berupa buku ajar Tema Peristiwa Dalam Kehidupan Berbasis Saintifik Di SD Negeri 008 Sangatta Utara.. Penelitian pengembangan ini menghasilkan kelayakan produk yang dikembangkan, dilakukan uji validasi yang melibatkan dosen ahli materi dengan skor rata-rata 4,71 ahli media dengan skor rata-rata 4,74 dan dosen ahli Bahasa Indonesia dengan skor rata-rata 4,81 serta uji coba pada siswa dengan skor ratarata 4,22 dengan kriteria sangat baik. Kriteria kepraktisan buku ajarl yang dikembangkan dengan persentase sebesar 89,28\% dan keefektifan buku ajar yang dikembangkan dengan persentase sebesar 84,4\% maka bahan ajar Tema Peristiwa Dalam Kehidupan Berbasis Saintifik Di SD Negeri 008 Sangatta Utara sangat layak digunakan. Untuk mencapai tujuan kegiatan belajar mengajar harus dilakukan secara efisien dalam implementasinya bersifat efektif dan efisien. Penilaian kelayakan bahan ajar ini meliputi empat aspek yaitu, aspek isi/materi, aspek penyajian, aspek bahasa dan aspek kegrafikan.
\end{abstract}

Kata kunci : Pengembangan, Peristiwa Dalam Kehidupan, Saintifik.

\section{ABSTRACT}

The purpose of this study was to develop teaching materials, practicality effectiveness and to find out the differences before and after using the textbook of event themes in Scientific-Based Life of SD Negeri 008 Sangatta Utara. This research was a development research or Research \& Development (R\&D). Research and Development was a research method used to produce certain products and to test validity, practicality and effectiveness of the product in the form of the textbook of event themes in Scientific-Based Life of SD Negeri 008 Sangatta Utara. This development research resulted in the feasibility of the product being developed. with an average score of 4.74 and Indonesian lecturers with an average score of 4.81 and trials on students with an average score of 4.22 with very good criteria. The practicality criteria of the textbook developed with a percentage of $89.28 \%$ and the effectiveness of the textbook developed with a percentage of $84.4 \%$, the teaching material event themes in Scientific-Based Life of SD Negeri 008 Sangatta Utara was very appropriate to use. To achieve the objectives of teaching and learning activities must have done efficiently in its implementation was effective and efficient. The assessment of the feasibility of teaching materials included four aspects namely, aspects of the content/material, aspects of presentation, aspects of language and aspects of graphics.

Keywords: Development, Events in Life, Scientific.

\section{PENDAHULUAN}

Pendidikan merupakan salah satu aspek penting dalam pembangunan negara sebagai sarana untuk meningkatkan kualitas sumber daya manusia, jika mutu pendidikan rendah maka kualitas sumber daya manusia dirasakan kurang mampu untuk bersaing. Karena itu, peningkatan mutu pendidikan tidak lepas dari upaya perbaikan salah satunya dengan pembaharuan kurikulum 2013 yang mengutamakan pemahaman, skill, dan pendidikan berkarakter, siswa dituntut untuk paham atas materi, aktif dalam berdiskusi dan 
presentasi serta memiliki sopan santun juga disiplin yang tinggi.

Pendekatan saintifik diterapkan dalam kurikulum 2013 mengacu pada menemukan konsep dasar yang melandasi penerapan model pembelajaran dengan menanamkan sikap ilmiah pada diri siswa dimana menyentuh tiga ranah yaitu sikap, pengetahuan dan keterampilan yang sesuai dengan penilaian dalam kurikulum 2013.

Selain siswa dan guru yang dituntut aktif yang perlu diperhatikan oleh pembuat kebijakan adalah sarana dan prasarana karena buku yang disediakan atau dikeluarkan pemerintah sangat susah untuk dipahami oleh siswa dan orang tua siswa apalagi untuk siswa kelas V SD.

Lemahnya kemampuan memecahkan masalah dan menalar/menganalisis adalah salah satu faktor penyebab rendahnya prestasi siswa Indonesia. Hal itu disebabkan karena lemahnya kemampuan siswa dalam bersikap kritis (Fitriadi \& Soe'oed, 2016). Kemudian, faktor penyebab lainnya adalah karena rendahnya kemampuan siswa menalar dan memecahkan masalah adalah pendekatan pembelajaran yang diterapkan. Muhibbin (2009: 155) mengatakan bahwa faktor pendekatan belajar berpengaruh terhadap taraf keberhasilan proses belajar siswa. Pembelajaran yang hanya menekankan hafalan tidak membuat kemampuan siswa menalar berkembang. Serta latar belakang tingkat kecerdasan orang tua siswa membuat cara belajar di rumah juga berbeda. Dengan adanya kenyataan seperti ini dilapangan peneliti melakukan terobosan dengan melakukan pengembangan bahan ajar pada tema peristiwa dalam kehidupan supaya di sekolah SD Negeri 008 Sangatta Utara dapat meningkatkan hasil belajar yang lebih baik dan menghasilkan bahan ajar yang mudah dipahami baik pengajar, siswa maupun orang tua.

Pembelajaran berbasis pendekatan saintifik diharapkan dapat memberikan pemahaman kepada siswa dalam mengenal dan memahami berbagai materi yang diberikan dengan menggunakan metode ilmiah. Siswa diajarkan menalar dan bagaimana mengambil keputusan, bukan berpikir mekanistis dengan hanya mendengar dan menghafal semata. Oleh karena itu, pembelajaran diarahkan untuk mendorong siswa aktif mencari tahu, mengembangkan kemampuan bernalar, dan membentuk siswa yang kreatif.

Tujuan penelitian ini adalah untuk mengetahui validitas, kelayakan hasil dan keefektifan pengembangan bahan ajar tema peristiwa dalam kehidupan berbasis saintefik di SDN 008 Sangatta Utara Kabupaten Kutai Timur.

\section{KAJIAN PUSTAKA}

Pengembangan adalah kegiatan ilmu pengetahuan dan teknologi yang bertujuan memanfaatkan kaidah dan teori ilmu pengetahuan yang telah terbukti kebenarannya untuk meningkatkan fungsi, manfaat, dan aplikasi ilmu pengetahuan dan teknologi yang telah ada, atau menghasilkan teknologi baru. Pengembangan secara umum berarti pola pertumbuhan, perubahan secara perlahan (evolution) dan perubahan secara bertahap.

Pada hakikatnya pengembangan adalah upaya pendidikan baik formal maupun non formal yang dilaksanakan secara sadar, berencana, terarah, teratur dan bertanggung jawab dalam rangka memperkenalkan, menumbuhkan, membimbing, mengembangkan suatu dasar kepribadian yang seimbang, utuh, selaras, pengetahuan, keterampilan sesuai dengan bakat, keinginan serta kemampuan-kemampuan, sebagai bekal atas prakarsa sendiri untuk menambah, meningkatkan, mengembangkan diri ke arah tercapainya martabat, mutu dan kemampuan manusiawi yang optimal serta pribadi mandiri (Wiryokusumo, 2016:19).

Bahan ajar adalah segala bentuk bahan yang digunakan untuk membantu guru/instruktur dalam melaksanakan kegiatan belajar mengajar di kelas. Bahan yang dimaksud bisa berupa bahan tertulis maupun tidak tertulis. Bahan ajar juga dapat diartikan sebagai informasi, alat maupun teks yang diperlukan atau digunakan oleh guru untuk merencanakan dan menelaah implementasi pembelajaran (Mudlofar, 2013:13). 
Bahan ajar merupakan seperangkat materi yang disusun secara sistematis baik tertulis maupun tidak tertulis sehingga tercipta lingkungan atau suasana yang memungkinkan siswa untuk belajar, seperti buku teks, handout, lembar kerja siswa, modul dan lain sebagainya. Istilah lain menyebutkan bahwa bahan ajar merupakan segala bentuk bahan yang digunakan untuk membantu guru atau instruktur dalam melaksanakan kegiatan belajar mengajar di kelas.

Pembelajaran tematik sebagai model pembelajaran termasuk salah satu tipe/jenis dari pada model pembelajaran terpadu. Istilah pembelajaran tematik pada dasarnya adalah model pembelajaran terpadu menggunakan tema untuk mengaitkan beberapa mata pelajaran sehingga dapat memebrikan pengalaman bermakna kepada siswa (Depdiknas, 2008; 5). Pembelajaran tematik lebih menekankan pada keterlibatan siswa dalam proses belajar secara aktif dalam proses pembelajaran, sehingga siswa dapat memperoleh pengalaman langsung dan terlatih untuk dapat menemukan sendiri berbagai pengetahuan yang dipelajarinya.

Dalam pelaksanaan pembelajaran tematik ada beberapa hal yang perlu dilaksanakan yang meliputi tahap perencanaan, yakni : pemetaan standar kompetensi yang mencakup penjabaran standar kompetensi dan kompetensi dasar, menentukan tema, identifikasi standar kompetensi, kompetensi dasar dan indikator, menetapkan jaringan tema, penyusunan silabus, silabus adalah rencana pembelajaran pada suatu kelompok mata pelajaran atau tema tertentu yang mencakup standar kompetensi, kompetensi dasar, materi pokok pembelajaran, kegiatan pembelajaran, indikator pencapaian kompetensi untuk penilaian, penilaian, alokasi waktu, dan sumber belajar (Trianto, 2016: 25).

Pembelajaran dengan pendekatan saintifik adalah proses pembelajaran yang dirancang sedemikian rupa agar peserta didik secara aktif mengkonstruksi konsep, hukum atau prinsip melalui tahapan-tahapan mengamati (untuk mengidentifikasi dan menemukan masalah), merumuskan masalah, mangajukan atau merumuskan hipotesis, mengumpulkan data dengan berbagai teknik, menganalisis data, menarik kesimpulan dan mengomunikasikan konsep, hukum atau prinsip yang “ditemukan”.

\section{METODE PENGEMBANGAN}

Penelitian ini merupakan penelitian pengembangan atau Research \& Development (R\&D). Research and Development adalah model penelitian yang digunakan untuk menghasilkan produk tertentu dan menguji keefektifan produk tersebut sesuai dengan kebutuhan masyarakat saat ini. (Sugiyono, 2012:11).

Uji coba produk dilakukan pada kelas V SD Negeri 008 Sangatta Utara yang berjumlah satu kelas yaitu kelas V SD yang terdiri dari 28 siswa. Pengambilan sampel secara purposive sampling dengan pertimbangan untuk memperoleh hasil yang baik dan ditentukan oleh guru, dipilih kelas dengan karakteristik siswa dapat bekerja sama dan kondusif, sehingga diharapkan dapat memberikan data yang maksimal.

Uji validasi bahan ajar diberikan kepada ahli materi, ahli media dan ahli bahasa hasil penilaian oleh ahli digunakan untuk mengetahui kevalidan bahan ajar yang dikembangkan.

Instrumen yang digunakan pada penelitian ini adalah lembar penilaian perangkat pembelajaran, angket respon siswa, lembar observasi keterlaksanaan kegiatan pembelajaran, dan tes kemampuan siswa. Lembar penilaian bahan ajar ini diberikan kepada satu guru ahli materi, ahli Bahasa dan ahli media hasil penilaian digunakan untuk mengetahui kevalidan bahan ajar yang dikembangkan berdasarkan aspek kelayakan isi dan penyajian materi dan kebahasaan.

\section{HASIL PENELITIAN DAN PEMBAHASAN}

Uji validasi pada produk ini dilakukan menggunakan lembar kuesioner/angket yang di dalamnya memuat aspek-aspek penilaian, yaitu aspek isi/materi, penyajian, bahasa, kegrafikan. Berikut disajikan data hasil validasi oleh ahli materi, ahli media, ahli Bahasa Indonesia dan uji 
coba terhadap siswa.

Data hasil validasi oleh team ahli materi, ahli media dan ahli bahasa meliputi aspek kelayakan isi/materi, penyajian, bahasa, dan kegrafikan dilakukan dengan memberikan penilaian di setiap aspek secara keseluruhan produk setelah direvisi.

Tabel 1 Rangkuman Data Validasi Ahli Materi pada Keseluruhan Aspek

\begin{tabular}{|c|c|c|c|c|}
\hline No & $\begin{array}{l}\text { Aspek } \\
\text { Penilaian } \\
\end{array}$ & $\begin{array}{c}\text { Skor } \\
\text { Rerata }\end{array}$ & $\begin{array}{c}\text { Persen } \\
\text { tase }\end{array}$ & $\begin{array}{l}\text { Kateg } \\
\text { ori }\end{array}$ \\
\hline 1. & $\begin{array}{l}\text { Kelayakan } \\
\text { isi/materi }\end{array}$ & 4,63 & $92,63 \%$ & $\begin{array}{l}\text { Sangat } \\
\text { Baik }\end{array}$ \\
\hline 2. & $\begin{array}{l}\text { Kelayakan } \\
\text { penyajian }\end{array}$ & 4,75 & $95,00 \%$ & \begin{tabular}{|l} 
Sangat \\
Baik
\end{tabular} \\
\hline 3. & $\begin{array}{l}\text { Kelayakan } \\
\text { bahasa }\end{array}$ & 4,50 & $90,00 \%$ & angat Baik \\
\hline \multirow[t]{3}{*}{4.} & $\begin{array}{l}\text { Kelayakan } \\
\text { kegrafikan }\end{array}$ & 4,90 & $98,18 \%$ & \begin{tabular}{|l} 
Sangat \\
Baik
\end{tabular} \\
\hline & Jumlah & 18,84 & $375,81 \%$ & \\
\hline & Skor rata-rata & 4,71 & $93,95 \%$ & \begin{tabular}{|l|} 
Sangat \\
Baik
\end{tabular} \\
\hline
\end{tabular}

Sumber: Data Primer, 2020

Berdasarkan tabel 1 di atas, hasil validasi yang dilakukan oleh dosen ahli materi pada aspek kelayakan isi/materi memperoleh skor rata-rata 4,63 atau 92,63\%, aspek kelayakan penyajian memperoleh skor rata-rata 4,75 atau 95\%, aspek kelayakan bahasa memperoleh skor rata-rata 4,5 atau 90\% dan aspek kelayakan kegrafisan memperoleh skor rata-rata 4,9 atau $98,18 \%$ dengan kategori "sangat baik". Hasil validasi oleh ahli materi dari keseluruhan aspek kelayakan materi, penyajian, bahasa dan kegrafikan memperoleh nilai rata-rata 4,71 dengan rata-rata persentase sebesar 93,95\% dengan kategori "sangat baik".

\section{Penilaian Ahli Materi}

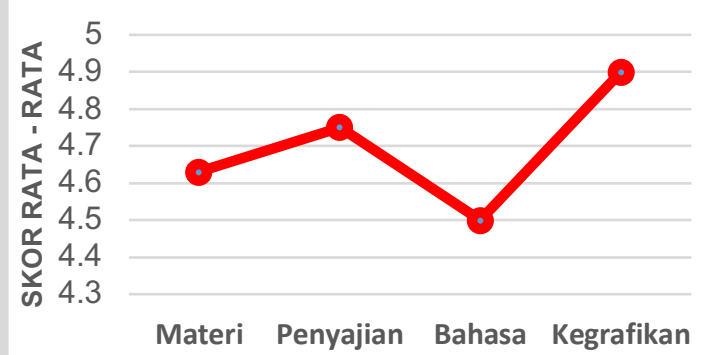

\section{Gambar: Grafik Hasil Validasi Dosen Ahli Materi}

Grafik di atas menunjukkan bahwa bahan ajar tema peristiwa dalam kehidupan berbasis saintifik memberikan penilaian dan memperoleh skor rata-rata terendah adalah aspek bahasa dengan skor 4,50 sedangkan aspek penilaian yang memperoleh skor tertinggi adalah aspek kegrafikan memperoleh skor rata-rata 4,90. Selain memberikan penskoran terkait kelayakan bahan ajar, dosen ahli materi yang memvalidasi juga memberikan saran perbaikan terhadap bahan ajar yang dikembangkan.

Tabel 2 Rangkuman Data Validasi Ahli Media pada Keseluruhan Aspek

\begin{tabular}{|r|l|c|c|l|}
\hline No & \multicolumn{1}{|c|}{$\begin{array}{l}\text { Aspek } \\
\text { Penilaian }\end{array}$} & $\begin{array}{c}\text { Skor } \\
\text { Rerata }\end{array}$ & $\begin{array}{l}\text { Persen } \\
\text { tase }\end{array}$ & $\begin{array}{l}\text { Kate } \\
\text { gori }\end{array}$ \\
\hline 1. & $\begin{array}{l}\text { Kelayakan } \\
\text { isi/materi }\end{array}$ & 4,84 & $96,84 \%$ & $\begin{array}{l}\text { Sangat } \\
\text { Baik }\end{array}$ \\
\hline 2. & $\begin{array}{l}\text { Kelayakan } \\
\text { penyajian }\end{array}$ & 4,63 & $92,50 \%$ & $\begin{array}{l}\text { Sangat } \\
\text { Baik }\end{array}$ \\
\hline 3. & $\begin{array}{l}\text { Kelayakan } \\
\text { bahasa }\end{array}$ & 4,67 & $93,33 \%$ & $\begin{array}{l}\text { Sangat } \\
\text { Baik }\end{array}$ \\
\hline \multirow{2}{*}{4.} & $\begin{array}{l}\text { Kelayakan } \\
\text { kegrafikan }\end{array}$ & 4,82 & $96,36 \%$ & $\begin{array}{l}\text { Sangat } \\
\text { Baik }\end{array}$ \\
\cline { 2 - 5 } & Jumlah & 18,96 & $379,03 \%$ & \\
\cline { 2 - 5 } & Skor rata-rata & 4,71 & $93,95 \%$ & $\begin{array}{l}\text { Sangat } \\
\text { Baik }\end{array}$ \\
\hline
\end{tabular}

Sumber: Data Primer, 2020

Berdasarkan tabel 2 di atas, hasil validasi yang dilakukan oleh ahli media pada aspek kelayakan isi/materi memperoleh skor rata-rata 
4,84 atau 96,84\%, aspek kelayakan penyajian memperoleh skor rata-rata 4,63 atau $92,5 \%$, aspek kelayakan bahasa memperoleh skor ratarata 4,67 atau 93,33\% dan aspek kelayakan kegrafisan memperoleh skor rata-rata 4,82 atau 96,36\% dengan kategori "sangat baik". Hasil validasi oleh ahli media dari keseluruhan aspek kelayakan materi, penyajian, bahasa dan kegrafikan memperoleh nilai rata-rata 4,74 dengan rata-rata persentase sebesar 94,75\% dengan kategori "sangat baik".

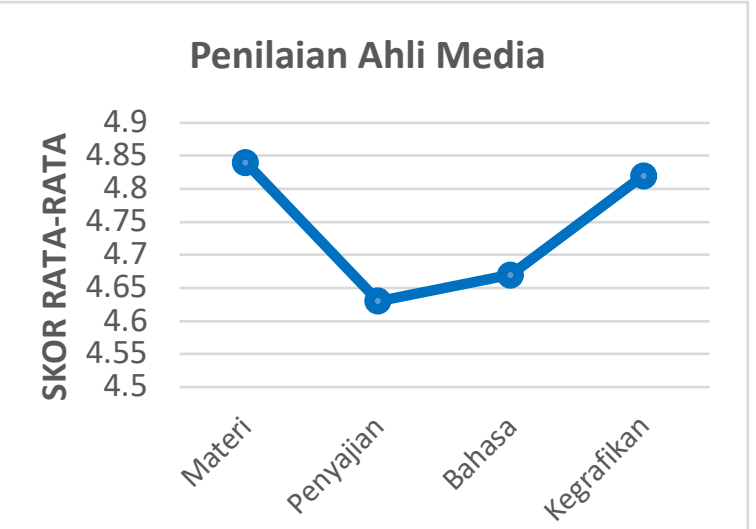

Gambar: Grafik Hasil Validasi Dosen Ahli Media skor rata-rata pada validasi tahap dua mengalami peningkatan. Aspek kebahasaan, penyajian dan kegrafikan yang pada tahap pertama mendapatkan nilai rendah mengalami peningkatan. Pada validasi tahap kedua secara berurutan dari nilai rata-rata terendah adalah aspek penyajian sebesar 4,63 aspek kebahasaann memperoleh skor rata-rata 4,67 aspek kegrafisan 4,82 dan aspek materi memperoleh skor rata-rata 4,78 .

Tabel 3 Rangkuman Data Validasi Ahli Bahasa pada Keseluruhan Aspek

\begin{tabular}{|c|l|c|c|l|}
\hline No & $\begin{array}{l}\text { Aspek } \\
\text { Penilaian }\end{array}$ & $\begin{array}{c}\text { Skor } \\
\text { Rerata }\end{array}$ & $\begin{array}{l}\text { Persen } \\
\text { tase }\end{array}$ & $\begin{array}{l}\text { Kate } \\
\text { gori }\end{array}$ \\
\hline 1. & $\begin{array}{l}\text { Kelayakan } \\
\text { isi/materi }\end{array}$ & 4,58 & $94,73 \%$ & $\begin{array}{l}\text { Sangat } \\
\text { Baik }\end{array}$ \\
\hline 2. & $\begin{array}{l}\text { Kelayakan } \\
\text { penyajian }\end{array}$ & 4,75 & $95,00 \%$ & $\begin{array}{l}\text { Sangat } \\
\text { Baik }\end{array}$ \\
\hline 3. & $\begin{array}{l}\text { Kelayakan } \\
\text { bahasa }\end{array}$ & 5,00 & $100,00 \%$ & $\begin{array}{l}\text { Sangat } \\
\text { Baik }\end{array}$ \\
\hline
\end{tabular}

\begin{tabular}{|c|l|c|c|l|}
\hline 4. & $\begin{array}{l}\text { Kelayakan } \\
\text { kegrafikan }\end{array}$ & 4,90 & $98,18 \%$ & $\begin{array}{l}\text { Sangat } \\
\text { Baik }\end{array}$ \\
\cline { 2 - 5 } Jumlah & 19,23 & $38791 \%$ & \\
\cline { 2 - 5 } & Skor rata-rata & 4,81 & $99,97 \%$ & $\begin{array}{l}\text { Sangat } \\
\text { Baik }\end{array}$ \\
\hline
\end{tabular}

Sumber: Data Primer, 2020

Berdasarkan tabel 3 dapat diketahui bahwa hasil validasi yang dilakukan oleh ahli bahasa pada aspek kelayakan isi/materi memperoleh skor rata-rata 4,58 atau $94,73 \%$, aspek kelayakan penyajian memperoleh skor rata-rata 4,75 atau 95\%, aspek kelayakan bahasa memperoleh skor rata-rata 5,00 atau 100\% dan aspek kelayakan kegrafisan memperoleh skor rata-rata 4,9 atau 98,18\% dengan kategori "sangat baik". Hasil validasi oleh ahli bahasa dari keseluruhan aspek kelayakan materi, penyajian, bahasa dan kegrafikan memperoleh nilai rata-rata 4,81 dengan rata-rata persentase sebesar $99,97 \%$ dengan kategori "sangat baik".

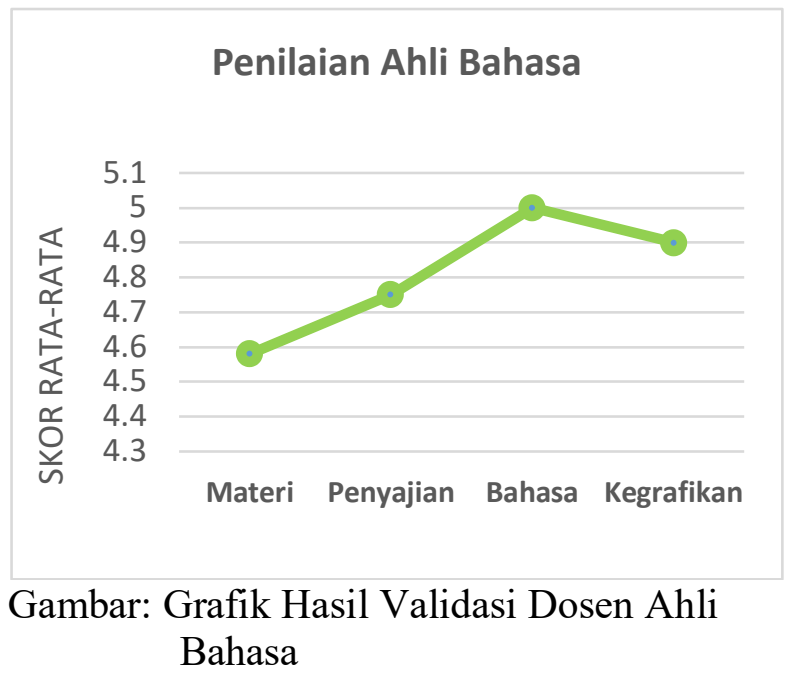

Ahli Bahasa yang melakukan validasi terhadap bahan ajar tema peristiwa dalam kehidupan berbasis saintifik untuk siswa SD kelas V memberikan penilaian dan memperoleh skor ratarata terendah adalah aspek kelayakan isi/materi dengan skor 4,58 aspek lelayakan penyajian memperoleh skor rata-rata 4,75. Aspek kelayakan kegrafisan 4,90 dsan nilai tertinggi adalah aspek kelayakan Bahasa yaitu nilai rata - rata sebesar 
5,00. Selain memberikan penskoran terkait kelayakan bahan ajar, dosen ahli Bahasa yang memvalidasi juga memberikan saran perbaikan terhadap bahan ajar yang dikembangkan. Kelayakan isi/materi.

Pada uji coba sekala besar yang diikuti oleh 28 siswa tentang sikap belajar siswa dan peningkatan kemampuan pengembangan bahan ajar berbasis saintifik. Menunjukkan bahwa hasil uji coba produk pada 28 siswa untuk keseluruhan aspek memperoleh skor rata-rata 4,22 atau $84,4 \%$ dengan kategori sangat baik berarti sangat efektif digunakan dalam kegiatan pembelajaran IPA.

Aspek kebahasaan dalam bahan ajar tema peristiwa dalam kehidupan berbasis saintifik menggunakan bahasa yang bersahabat sehingga lebih praktis, efektif dan mudah dimengerti. Daryanto (2013:11)

Tabel Data Sekor Uji Coba Siswa pada Keseluruhan Aspek

\begin{tabular}{|c|c|c|c|}
\hline No. & Aspek & $\begin{array}{c}\text { Skor Rata- } \\
\text { Rata }\end{array}$ & Kategori \\
\hline 1 & $\begin{array}{l}\text { Kelayakan } \\
\text { isi/materi }\end{array}$ & 4,08 & $\begin{array}{l}\text { Sangat } \\
\text { Baik }\end{array}$ \\
\hline 2 & $\begin{array}{l}\text { Kelayakan } \\
\text { penyajian }\end{array}$ & 4,27 & $\begin{array}{l}\text { Sangat } \\
\text { Baik }\end{array}$ \\
\hline 3 & $\begin{array}{l}\text { Kelayakan } \\
\text { bahasa }\end{array}$ & 4,24 & $\begin{array}{l}\text { Sangat } \\
\text { Baik }\end{array}$ \\
\hline $\begin{array}{l}4 \\
.\end{array}$ & $\begin{array}{l}\text { Kelayakan } \\
\text { kegrafikan }\end{array}$ & 4,29 & $\begin{array}{l}\text { Sangat } \\
\text { Baik }\end{array}$ \\
\hline & Jumlah & 16,88 & \\
\hline & Skor rata-rata & 4,22 & $\begin{array}{l}\text { Sangat } \\
\text { Baik }\end{array}$ \\
\hline & Persentase & $84,4 \%$ & $\begin{array}{l}\text { Sangat } \\
\text { Baik }\end{array}$ \\
\hline
\end{tabular}

Sumber: Data Primer, 2020

Data di atas menunjukkan bahwa hasil uji coba produk pada 28 siswa untuk keseluruhan aspek memperoleh skor rata-rata 4,22 atau 84,4\% dengan kategori sangat baik berarti sangat efektif digunakan dalam kegiatan pembelajaran IPA..

Pada kegiatan belajar siswa dalam mengikuti pembelajaran berbasis saintifik sudah sangat baik dan keaktifan belajar yang sangat antusias dalam mengikuti pembelajaran begitu juga dengan perhatian siswa terhadap materi yang disampaikan dan keaktifan siswa termasuk dalam kategori baik sekali.

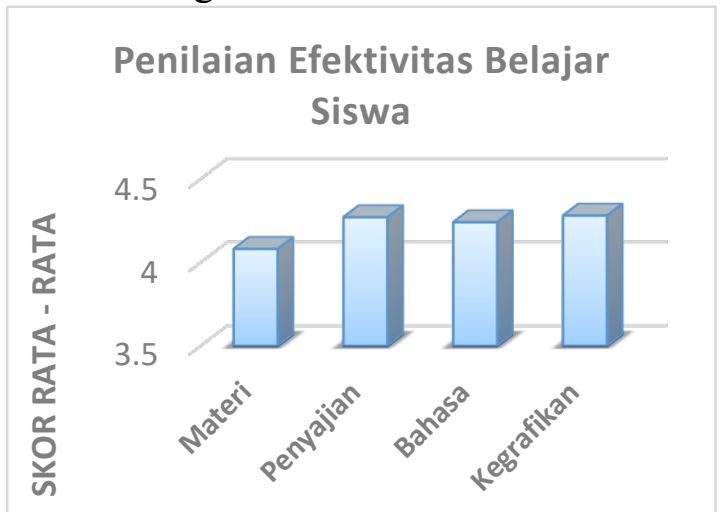

Gambar: Diagram Batang Penilaian Efektivitas Belajar

Pengembangan bahan ajar berbasis saintifik dapat meningkatkan kemampuan hasil belajar siswa kelas V SD. Hasil belajar dengan penerapan bahan ajar diperoleh dari hasil uji kompetensi keterlaksanaan kegiatan pembelajaran dan angket respon siswa. Sungkono (2013: 16) menjelaskan bahwa bahan ajar yang dikembangkan dapat membantu dan membeikan kemudahan bagi penggunanya. Hasil kegiatan pembelajaran pada tindakan awal dengan nilai rata-rata kelas adalah 51,88 atau 51,85\%, dengan kategori cukup dapat diterapkan, pertemuan pertama nilai rata-rata kelas adalah 61,88 atau $61,85 \%$ dengan kategori dapat diterapkan dan pertemuan kedua nilai ratarata kelas adalah 80,71 atau $80,71 \%$ dengan sekor ideal adalah 100 dengan klasifikasi sangat dapat diterapkan.

Sebelum dan sesudah menggunakan bahan ajar dilakukan pretest dan post-test untuk mengetahui kemampuan pemecahan masalah siswa. Hasil analisis nilai pretest untuk siswa tuntas hanya 1 siswa atau sebesar 7,12\% sesudah post-test pada siklus pertama untuk siswa tuntas sebanyak 9 siswa atau sebesar 32,14\% sedangkan persentase ketuntasan siswa pada post-test pengambilan nilai formatif ke II berjumlah 26 siswa atau sebesar $92,86 \%$. 
Berdasarkan analisis hasil pretest dan posttest persentase ketuntasan siswa lebih dari $75 \%$, maka bahan ajar yang dikembangkan memiliki kualitas sangat praktis dan efektif. Perangkat pembelajaran dikatakan efektif jika bahan ajar yang digunakan dapat membatu siswa mencapai kompetensi yang harus dimilikinya (Hamdani. 2011: 48). Berdasarkan uraian tersebut dapat disimpulkan bahwa bahan ajar IPA pada siswa kelas V SD tema peristiwa dalam kehidupan berbasis saintifik yang dikembangkan memiliki kualitas valid, praktis, efektif dan dapat meningkatkan hasil belajar sehingga sangat dapat diterapkan dalam proses belajar mengajar.

\section{KESIMPULAN}

Validitas pengembangan bahan ajar pada aspek isi/materi, penyajian, bahasa, dan kegrafikan dari ahli materi sebesar 4,71 atau 93,95\% dan ahli media sebesar 4,74 atau 94,75\% serta ahli Bahasa sebesar 4,81 atau 99,97\% dengan kategori sangat baik dan sangat valid.

Kelayakan hasil pengembangan buku ajar dengan tema peristiwa dalam kehidupan berbasis saintifik dilakukan validasi oleh ahli materi, ahli media dan ahli bahasa mencakup aspek kelayakan isi/materi, kelayakan penyajian, kelayakan kebahasaan dan kelayakan kegrafikan. Keempat aspek diakumulasikan, buku ajar dengan tema peristiwa dalam kehidupan berbasis saintifik memperoleh skor rata-rata sebesar 4,81 dengan persentase kelayakan sebesar 99,97\% dengan kategori sangat baik dan sangat layak digunakan.

Keefektifan bahan ajar buku ajar tema peristiwa dalam kehidupan berbasis saintifik dimulai dengan uji coba produk dilakukan oleh 28 siswa memperoleh skor rata-rata sebesar 4,24 atau $84,7 \%$ dengan kategori sangat baik, yang mencakup aspek kelayakan isi/materi, kelayakan penyajian, kelayakan kebahasaan dan kelayakan kegrafikan. Dengan demikian maka buku ajar yang dikembangkan memiliki kualitas valid, praktis, efektif dan dapat meningkatkan hasil belajar sehingga sangat dapat diterapkan dalam proses belajar mengajar di kelas V Sekolah Dasar.

\section{DAFTAR PUSTAKA}

Daryanto. 2014. Pendekatan Pembelajaran Saintifik Kurikulum 2013. Penerbit Gava Media: Yogyakarta.

Depdiknas. 2012. Pendidikan Pengembangan Bahan Ajar. Kementrian Pendidikan dan Kebudayaan Direktorat Jendral Pendidikan Dasar Direktorat Pembinaan Sekolah Dasar: Jakarta

Fitriadi, A., \& Soe'oed, R. (2016). The

Correlation between Critical Thinking Skills and Critical Thinking Dispositions of the Fifth Semester Student of English

Department in Academic Years 2015/2016.

Konferensi Antarabangsa Islam Borneo Ke9 (KAIB IX), 9(25), 250.

Mudlofar, Ali. 2013. Aplikasi Pengembangan Kurikulum Tingkat Satuan Pendidikan dan Bahan Ajar Dalam Pendidikan Islam. Rajawali Press: Jakarta

Muhibin, Syah. 2009. Psikologi Pendidikan Dengan Pendekatan Baru. Rineka Cipta: Bandung

Wiryokusumo, Iskandar. 2016.Dasar - Dasar Pengembangan Kurikulum. Rineka Cipta: Jakarta

Sugiyono. 2012. Metode Penelitian Pendekatan Kuantitatif, Kualitatif dan $R \& D$. Alfabeta: Bandung

Sungkono. 2013. Teori-Teori Belajar. Erlangga: Jakarta

Trianto. 2016. Mendesain Model Pembelajaran Inovatif Progresif. Kencana Prenada Media Group: Surabaya 